\title{
Eco-friendly Management of Blast (Magnaporthe oryzae) of Rice
}

\author{
Jiwan Paudel ${ }^{1 *}$, Saroj Belbase ${ }^{1}$, Shrvan Kumar ${ }^{2}$, Rivesh Bhushal, \\ Ramu Yadav and Dipak Yadav \\ ${ }^{1}$ Rajiv Gandhi South Campus, Banaras Hindu University, Barkachha, \\ Mirzapur 231001, UP, India \\ ${ }^{2}$ Mycology and Plant Pathology, IAS, Banaras Hindu University, Varanasi-221 005, (U.P.), \\ India \\ *Corresponding author
}

\section{A B S T R A C T}

\section{Keywords}

Rice blast; Magnaporthegrisea; Integrated; Bio control agents

\section{Article Info}

Accepted:

24August 2019

Available Online:

10 September 2019
Rice blast caused by Magnaporthe grisea (Hebert) Barr (Anamorph: Pyricularia grisea (Cooke) Sacc.) is a key concern in combating global food insecurity given the disease is responsible for approximately $30 \%$ of rice production losses globally - the equivalent of feeding 60 million people. This loss increases the global rice price and reduces consumer welfare and food security. Chemicals are commonly applied for controlling rice blast disease, but when chemicals are used indiscriminately, they also pose a serious threat to the environment. Control methods like resistant cultivars, healthy seed, fertilizer management, cultural systems, burning or composting of diseased tissues and chemical control are commonly used. In chemical control uses of any one fungicide i.e. tricyclazole (Beam 75WP)@0.75g/L, edifenphos (Hinosan 35WP) @1 g/L, iprobenfos (Kitazin 48EC) 1.0g/L, mancozeb (Dithane M-45) @ 2.5g/L,blasticidin (Bla-S) @ 0.1g / L, thiophanatemethyl (Neotopsin 70WP)@ 0.5g/l, difenconazole (Score 25 EC) @ 1.0g/l, hexaconazole (Contaf $25 \mathrm{EC}$ ) @ 1.0g/L, propiconazole (Tilt $25 \mathrm{EC}$ ) @ 1.0g/Lhave thepotential to be used as highly effective against rice blast disease.(59.99\%). Any oneuses of biopesticides namely, Achook (5ml), Spictaf $(4.5 \mathrm{ml})$, Neem-Azal $(3 \mathrm{ml})$,Neem gold $(10 \mathrm{ml})$ Nimbicidine $(5 \mathrm{ml})$, Wanis $(5 \mathrm{ml})$ and tulsi leaf extract $(10 \mathrm{ml})$ and biocontrolagents like P.fluorescens (Bioshield-5ml), Gliocladium virens (Soilgard-5g)and Trichoderma harzianum (Bioderma-5g) Trichoderma viride(Ecoderma-5g)asseed treatment per $\mathrm{kg}$ and foliar sprays per liter thrice at tillering, booting and panicle initiation stagemost effective in reducing the disease incidence.Silicon compounds are recognized and classified as biostimulants in rice crop. These are increase defense mechanism against direct penetration of pathogens. So, One foliar spray of KSi @ 4 g/L or NaSi@0.5g/L should be applied on the 22nd day after emergence. Integrated disease management is the best method to solve problems of pests and it is combination of different methods to control pests in sound environmental management and cost effective way.

\section{Introduction}

Rice (Oryza sativa L.)- Asian and (Oryza glaberrima Notteghem, 1991) is a member of family Gramineae. Nearly half of the world 
population, including all of East and Southeast Asia, is solely dependent upon rice as a staple food; humans eat 95 percent of the world's rice crop. Globally during 2017-18, rice crop occupied an area of about 162.62 million hectares with 495.07 million metric tonnes of production and productivity of 4.54 metric tonnes per hectare (USDA, 2018). China ranks first in rice production followed by India and Indonesia in second and third place respectively.

In India Total Rabi Rice production during 2017-18 was estimated to be 15.41 million tonnes which is 2.01 million tonnes more than total rabi rice production in 2016-17 and 1.71 million tonnes more than the five years' average production of Rabi rice. Total production of Kharif rice was 99.24 million tonnes which is 1.74 million tonnes than the last year's production.Further, it is higher by 6.64 million tonnes over the average production of Kharif rice during the last five years (Department of agriculture cooperation and farmer welfare)

Since the appearance of blast in China by Soong ying-shin in 1637(Manibhushan Rao, 1994), blast has outbroke recurrently several times infecting rice grown all over the world. Each year rice ample to feed 60 million people is destroyed by blast alone(Zeigler et al., 1994). Environments with higher humidity and with lower day temperature, high dose of nitrogenous fertilizer are more favorable to blast (Chiba et al., 1996; Liu et al., 2004).Pyricularia griseacan damage more than 80 graminaceous hosts (Urashima et al., 2007). (Galbieri and Urashima 2008) found that pathogen can cause significant damage on wheat, triticale and barley.

\section{Economic importance}

Grainloss of 75 per cent has been reported in India (Padmanabhan 1965), 40 per cent in
Nigeria (Ou 1985),30-50 percent in China (Huang et al.,2005), 50 per cent in Philippines (Awodera and Esuruoso 1975) and. 10-20 per cent yield loss in susceptible varieties, but in severe cases up to 80 per cent loss in Nepal (Manandhar et al., 1992). (Chandrasekhara et $a l ., 2008)$ reported that rice blast caused by $P$. oryzae is one of the devastating disease of rice resulting in yield losses up to $65 \%$ in susceptible rice cultivars. Mahesh et al., (2012) recounted that the damage of blast in terms of grain yield under conventional system of rice cultivation was 8.2 percent and in System of Rice Intensification (SRI) methods 7.5 percent respectively. The pathogen lead to the annual destruction of approximately $10-30 \%$ of the rice harvested globally (Fernandez and Orth, 2018).

\section{Host range}

Many research workers demonstrated that although M. grisea can infect a wide range of plant hosts, some strains are species and even cultivar specific (Valent and Chumley 1991, Borromeo et al.,1993). Kumar and Singh (1994) reported that Pyricularia grisea is parasitic on number of host plants belonging to the family Gramineae which includes cereals and grasses such as Oryza sativa, Eleusine coracane, Eleusine indica, Digitaria sanguinalis, Pennisetum typhoides, Echinochloa colonum(Urashima et al.,2007) reported that Pyricularia grisea is pathogenic on more than 80 graminaceous host plants. The pathogen is also pathogenic on wheat, triticale and barley and is responsible for causing significant yield losses in these crops (Galbieri and Urashima 2008). P. griseais also reported on the following plants: Agropyron repens, Agrostis palustris, A. tenuis, Alopecurus pratensis, Andropogon sp., Anthoxanthum odoratum, Arundo donax, Avena byzantina, A. sterilis, A. sativa, Brachiaria mutica, Bromus catharticus, The role of these host plants in the rice blast 
disease cycle remains subject of controversy (Borromeo et al.,1993)

\section{Taxonomic position}

Hori (1898) compared the Japanese blast fungus with American specimen referred to as Pyriculariagriseaand maintained that P.grisea produced 3-5 conidiophores while P.oryzae produced only one conidiophore. The causal organism was named as Pyricularia grisea by Saccardo in 1880 and as Pyricularia oryzae by Cavara in 1891(Rosseman et al., 1990). The names P.grisea and P.oryzae have been used by different workers at different times. The pathogen belongs to sub-division Deuteromycotina, class Hyphomycetes, order Moniliales and family Dematiaceae.

\section{Morphology of the pathogen}

Hossain (2000) observed mycelium in cultures was first hyaline in colour, then changed to olivaceous, $1-5.2 \mu \mathrm{m}$ in width, septate and branched. The spore measurements were $15-$ $22 \mu \mathrm{m}$ x $4-7 \mu \mathrm{m}$ (Average, $17.4 \mu \mathrm{m}$ x $5.2 \mu \mathrm{m}$ ). (Nishikado 1917) described conidial morphology of $P$. grisea, which measured 16$33 \times 5-9 \mu \mathrm{m}$, usually $22-27 \times 7-8 \mu \mathrm{m}$, with a small basal appendage. Other dimensions were basal appendage 1.2-1.8 $\mu \mathrm{m}$ in width, basal cell 4.8-11.5 $\mu \mathrm{m}$, middle cell $1.8-11.5 \mu \mathrm{m}$ and apical cell with 6-14 $\mu \mathrm{m}$ in length. (Veeraraghavan and Padmanabhan 1965) reported that the dimensions of conidia produced by $P$. oryzae ranged from 17.6 to $24.0 \mu \mathrm{m}$ in length and 8.0 to $9.6 \mu \mathrm{m}$ in width.

\section{Effect of $\mathrm{pH}$ on growth of the pathogen}

Sy et al.,(1977) studied the effect of $\mathrm{pH}$ on the mycelial growth, formation of conidia and conidial germination of $P$. oryzae. They observed that increase in mycelial growth occurred at all the $\mathrm{pH}$ levels except $2.35-$ 2.95. Mycelial growth was maximum at $\mathrm{pH} 4$
-6 , formation of conidia was maximum at $\mathrm{pH}$ $4.60-6.45$ and germination of conidia was best at $4.60-5.45$. The increased in growth of P.oryzae was seen from 3.5 to 6.5 with maximum growth at $\mathrm{pH} 6.5$ and least at $\mathrm{pH}$ 3.5 (Hossain, 2000)

\section{Symptoms and Histopathology}

Rice blast pathogen infect all the above ground parts of rice plants at different growth stages, i.e, leaf, collar, nodes, internodes, base or neck and other parts like panicle and leaf sheath Castilla et al.,(2009), also on rachis, joints of the culm and even on the glume (Manandhar 1996).

\section{Symptoms}

Leaf blast-lesions may initially appear graygreen and water-soaked with a dark green border, which expand, rapidly to several centimeters in length often becoming light tan in color with necrotic borders (Plate-1). On resistant cultivars, lesions often remain small in size (1-2 mm) and brown to dark brown in color which may vary according to environmental conditions (Tebeest et al.,2007). When the fungus attacks young leaves, purple spots could be observed changing into spindle shape having gray centre and purple to brown border. Brown spots appeared only on older leaves or leaves of resistant cultivars (Hajimo, 2001). At the severely case the nursery infection leads to burnt appearance. Nodal / Collar blast-A region of necrosis at the junction of leaf and the stem sheath. Collar infections can kill the entire leaf and may extend a few millimetres into and around the sheath. The fungus produces abundant spores on these lesions (Padmanabhan, 1974 and Manibhushanrao, 1994). (Ram et al., 2007) reported that when the last node is attacked, it causes partial to complete sterility. Panicle/ neck blast- neck blast are characterized by infection at panicle 
base (Plate-1), it is the most destructive phase of the disease and is found at the reproductive and ripening stage of the crop (Bonman et al., 1991).

The node immediately below the ear is infected and become dark brown to black in colour, the symptom is called neck infection. The infected panicles often break and fall off, or the whole inflorescence may break off at the rotten neck. Seed blanking-Seeds are not produced when pedicels become infected, a condition called blanking (Plate-1). In case of early neck infection inhibition of grain filling, whereas partial grain filling in the late infection is seen (Padmanabhan 1974 and Manibhushanrao, 1994).

\section{Disease cycle}

Magnoporthe gresea and $M$. oryzae have a hemibiotrophic life style, in which the fungus undergoes an initial biotrophic stage during which the plant immune system is suppressed, and then switches to a necrotrophic stage that promotes plant cell death. The primary source of inoculum present in rice straw, seeds, weeds, planting debris, soil, bamboo or bamboo grass or on alternate hosts in the form of mycelium which retains it variability up to the new growing season. The blast fungus survives as mycelia in plant residues, conidia or in living plant tissue; in tropical and subtropical areas, all three modes are considered important as sources of initial inoculum. Air, water or seed may also transport conidia. Mycelia surviving in rice straw have been found to remain viable for up to 3 years at $18-32^{\circ} \mathrm{C}$ and to produce conidia when moistened, while conidia are reportedly viable for 1 year at $8^{\circ} \mathrm{C}$ and $20 \% \mathrm{RH}$. Although $M$. grisea conidia are associated with seed, there is no evidence that seed infection plays a role in initiating epidemic. In paddy rice ecosystems, puddling greatly reduces survival of conidia in rice refuse or
seeds.(URL-1).There are three seasons for growing rice in India viz. autumn, winter and summer. Some states like Assam, Bihar Orissa East U.P., West Bengal, Andhra Pradesh, Karnataka and Kerala are growing all three seasons. So, primary inoculum is present throughout year and disease also present (URL-2). In irrigated rice areas such those of Tamil Nadu, India, it is common to find germinated rice seedling around threshing flats in villages which grow two rice crops a year. The storage of rice straw for cattle feed and the use of the straw as thatching in many South Asian villages also provides other sources. In intensively cropped irrigated rice areas, such as the triple-cropped Mekong Delta in Vietnam, the turnaround period between successive rice crops is as short as 15 days in some provinces. Not all fields are fully synchronized in each province and it is common to find live rice tissue throughout the year(URL-3).

\section{Epidemiology and Phytopathometry}

Khan and Libby (1958) Reported that the optimum temperature for lesion development was $27-29^{\circ} \mathrm{C}$ and the minimum temperature was $14-15^{\circ} \mathrm{C}$. They also reported that the optimum temperature for disease development and sporulation was $22-26^{\circ} \mathrm{C}$. Munoz (2008) reported that maximum concentration of airborne spores was 0.8 per $\mathrm{cm}^{2}$ recorded between the $20^{\text {th }}$ and $25^{\text {th }}$ August with relative humidity of $95 \%$ and the average temperature was around $26^{\circ} \mathrm{C}$. Second maximum spore concentration of 0.5 spores per $\mathrm{cm}^{2}$ was observed between $25^{\text {th }}$ to $30^{\text {th }}$ of September. This period was optimum for blast infection. Saifulla et al.,(2011) find out that Rice blast severity reduced gradually with increased in minimum temperature from $19^{0} \mathrm{C}$ to $26^{0} \mathrm{C}$. The rice blast severity was increased with increase of rainfall from $5 \mathrm{~mm}$ to $17 \mathrm{~mm}$. The rice blast severity increased with increase of relative humidity from 72 to $90 \%$. Tebeest et 
al.,(2007) reported that period of high moisture of 12 hours or more with temperature of $24^{\circ} \mathrm{C}$ was highly favorable for the development of the disease. Resistance to blast is governed not only by genetic factors but also by a set of very critical environmental factors including night temperature $\left(20^{\circ} \mathrm{C}\right)$ which influence the metabolic pattern of the host (Subramanian 1967). Even growing host plant continuously at low temperature can lead to partial breakdown of resistance (Manibhushanrao and Day 1972). (Leung et al., 1988) reported that the average life span of resistant rice cultivar is 2 to 3 years.

\section{Phytopathometry}

The prevalence of the disease was calculated using the number of fields affected by the disease divided by the total number of fields assessed and expressed in percentage. Scoring scale of blast disease under field condition was rated according to standard International Rice Research Institute (IRRI) scale of 0-9 (IRRI, 2009 and Asfaha et al., 2015).

\section{Integrated disease management}

Scouting for blast should begin early in the season starting at tillering and continuing through heading. Leaf blast usually appears in elevated areas of the field where the irrigated water is shallow or has been lost. Loss of floodis the most favorable agronomic practice that favors blast.

Blast is several times more severe under upland conditions than when flooded because aerobic environment favors the pathogen. If the flood must be removed for insect control, herbicide damage, straight head control, or some other reason, reestablish the flood as soon as possible and scout regularly for blast (Groth, 2011). Hence, integration of possible cultural practices like well managed flooded and fertilized with optimum $\mathrm{N}$ application field is necessary along with fungicidal application. Kamel and Sharkawy (1989) reported that the pathogen is extremely variable and its management required short and long term measures.

These include exclusion through strict quarantine, cultural practices such as early planting, elimination of alternative hosts, chemotherapy and breeding varieties with stable resistance.

\section{Resistant cultivar}

Uses of resistant varieties ontropical lowland condition (IR 20, IR 36, IR 42), temperate lowland (Fu She 94, Shuang Feng 4, Xiang Ai Zao 9, Zhenluon 13), upland condition (Fukuton, IAC 25, Kuroka, Moroberekan, OS 6) (Bonman and Mackill, 1988).

In India, some resistant cultivars developed for the disease are Co 4, TKM-1, Co-29, Co30, T-603, T-141, A-67, A-90, A-200, A-249, IR-579, NLR 34449 and Bala late-6.

Twelve elite germplasm viz; HPR- 917, HPR933, HPR- 977, HPR- 1001,HPR- 1009, HPR1020, HPR- 1062, HPR- 1064, HPR- 1153, HPR- 1155, HPR-1161 and HPR- 1174 and six released varieties viz; Himalaya 741, Himalaya 799,Himalaya 2216, RP-2421, IR 64 and Palam Dhan 957 resistant against rice blast (Sharma, 2006).

\section{Cultural control}

Field sanitation and synchronized planting reduce carryover and/or spread of disease. Excessive nitrogen fertilization is known to increase blast severity. So, uses of proper nitrogen fertilizers (Long et al., 2000). Application of Sodium silicate (NaSi) @ $0.15 \mathrm{~g} / \mathrm{L}$ (Laane, 2018) or potassium silicate @ $4 \mathrm{~g} / \mathrm{L}$ (Buck, 2008) on the 22nd day after emergence. Silicon compounds has been 
shown to have a high impact on plantpathogen interactions and a silicon input improves rice tolerance against blast (Seebold et al., 2000).

Uses of no-tillage system decrease in blast severity as compared to the conventional cropping system (Sester et al., 2013).

Crop sowing into water eliminates disease transmission because of the anaerobic condition, which is adverse to the pathogen (Sester et al., 2013)

\section{Bio-pesticides control}

Any one uses of biopesticides namely, Achook (5ml), Spictaf (4.5 ml), Neem-Azal (3 $\mathrm{ml})$, Neem gold $(10 \mathrm{ml})$ Nimbicidine $(5 \mathrm{ml})$, Wanis $(5 \mathrm{ml})$ and tulsi leaf extract $(10 \mathrm{ml})$ and biocontrol agents like P.fluorescens (Bioshield-5ml), Gliocladium virens (Soilgard-5g)and Trichoderma harzianum (Bioderma-5g) Trichoderma viride (Ecoderma-5g)as seed treatment per $\mathrm{kg}$ and foliar sprays per liter thrice at tillering, booting and panicle initiation stage most effective in reducing the disease incidence (Anonymous, 2000, Hossain and Kulkarni 2001; Sharma, 2006).

\section{Chemical control}

Uses of any one fungicide i.e. tricyclazole (Beam 75WP)@0.75g/L, edifenphos (Hinosan 35WP)@1g/L, iprobenfos (Kitazin 48EC) $1.0 \mathrm{~g} / \mathrm{L}$, mancozeb (Dithane M-45) @ 2.5g/L, blasticidin (Bla-S) @ 0.1g / L, thiophanatemethyl (Neotopsin 70WP)@ 0.5g/l, difenconazole (Score 25 EC) @ 1.0g/l, hexaconazole (Contaf 25 EC) @ 1.0g/L, propiconazole (Tilt $25 \mathrm{EC}$ ) @ 1.0g/L have the potential to be used as highly effective against rice blast disease(Arun et al., 2011; Singh et al., 2011; Hajano et al., 2012).

Seed treatment with carbendazim @ 2g/kg + spraying of tricyclazole @ $0.06 \%$ + spraying of plant extract of Ocimum sanctum @ 15\%,7 days of first spray + spraying of Pseudomonas fluorescens @ 0.4 g/1 after 7 days of first spray (Varaprasada et al., 2018)

Seed treatment with carbendazim @ 2g/kg + spraying of tricyclazole @ $0.06 \%$ + second spray of tricyclazole @ 0.06\% after 7 days of first spray (Varaprasada et al., 2018)

The major biotic challenge for rice production comes through blast disease. To overcome these confrontfarmers and growers started arbitrary use of chemical pesticide.

It destroyed the balance of ecosystem and imposed health risk to consumers. Pest resistance against such chemicals has also been reported. Complete dependence on cultural, mechanical and biological control is also not practical.

Hence considering all above challenges we tried to combine maximum possible minimum/non chemical approaches in one platform, which earlier was scattered or confined, to the only research.

This review suggests some eco-friendly management approach for significantly important and serious blast of rice. Ecofriendly approaches not only will reduce excessive chemical use but also improves quality of produce and soil health. If these methods are implemented right from field preparation to harvesting and storage this will lead to low chances of disease development (or) at least to maintain it to below Economic Injury Level/ Economic Threshold Level. 
Table.1

\begin{tabular}{|c|l|}
\hline Scale & \multicolumn{1}{|c|}{ Disease reaction } \\
\hline $\mathbf{0}$ & No lesions \\
\hline $\mathbf{1}$ & Small brown speaks of pin point size or large brown speck without speculating centre \\
\hline $\mathbf{2}$ & $\begin{array}{l}\text { Small round dish to slightly elongated necrotic grey spots about 1-2 mm in diameter with } \\
\text { distinct brown margin lesions are mostly found on lower leaves. }\end{array}$ \\
\hline $\mathbf{3}$ & $\begin{array}{l}\text { Lesion type is the same as in scale 2, but significant number of lesion are on the upper } \\
\text { leaves. }\end{array}$ \\
\hline $\mathbf{4}$ & Typical blast lesion infecting less than 2\% of the leaf area. \\
\hline $\mathbf{5}$ & Typical blast lesion infecting 2-10\% of the leaf area. \\
\hline $\mathbf{6}$ & Typical blast lesion infecting 11-25\% of the leaf area. \\
\hline $\mathbf{7}$ & Typical blast lesion infecting 26-50\% of the leaf area. \\
\hline $\mathbf{8}$ & Typical blast lesion infecting 51-75\% of the leaf area, many leaves dead. \\
\hline $\mathbf{9}$ & More than 75\% of the leaf area affected. \\
\hline
\end{tabular}

Plate.1 Symptom of Leaf blast, neck blast and seed blanking in rice
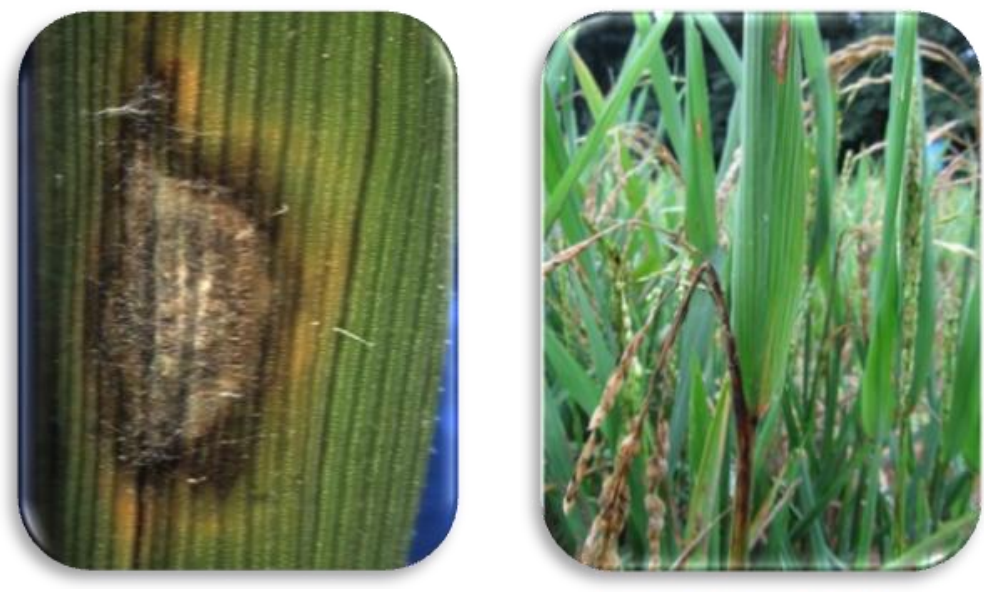

References

Anonymous. 2000. Department of agriculture cooperation and farmers welfare Link http://pib.nic.in/newsite/PrintRelease.a spx? relid=186796

Arun, K.S, Sachin, U and Ajay, S. 2011. Field evaluation of insecticides and fungicides for the control of whorl maggot, Hydrellia philippina and rice

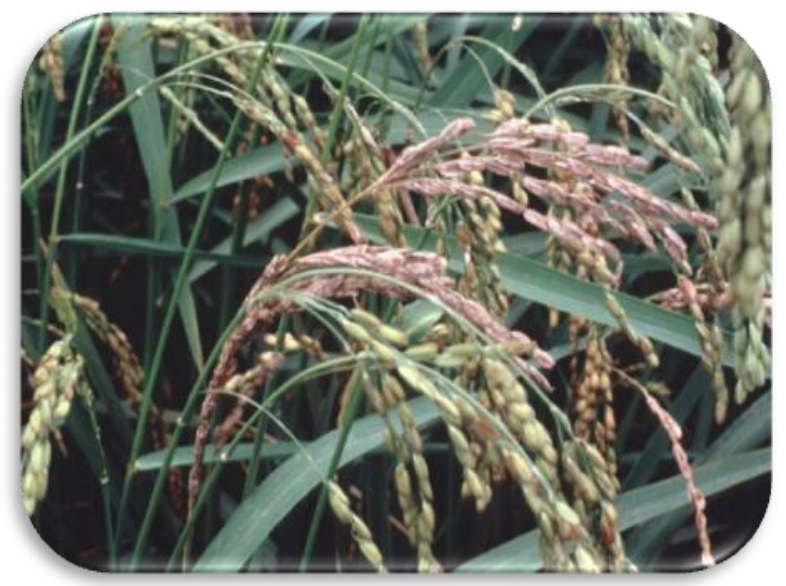

blast caused by Pyriculariagrisea. Oryzae. 48 (3): 280-281.

Asfaha, M. G., Selvaraj, T. and Woldeab, G. 2015. Assessment of disease intensity and isolates characterization of blast disease (Pyricularia oryzae CAV.) from South West of Ethiopia. Int. J. of Life Sciences, 3(4): 271-286.

Awodera V. A. and Esuruoso O. F. 1975. Reduction in grain yield of two rice 
varieties infected by rice blast disease in Nigeria. Nigerian Agric J 11:17073.

Bonman J. M., Estrada B. A., Kim C. K., Ra D. S. and Lee E. J. 1991. Assessment of blast disease and yield loss in susceptible and partially resistant rice cultivars in two irrigated low land environments. Pl Dis 75:462-66.

Bonman, J.M., and Mackill, D.J. 1988. Durable resistant to rice blast disease. Oryza 25: 103.

Borromeo E.S., Nelson R. J., Bonman J. M. and Leung H. 1993. Genetic differentiation among isolates of Magnaporthe grisea infecting rice and weed hosts. Phythopathology83: 39399.

Buck, G.B.; Korndörfer, G.H.; Nolla, A. and Coelho, L. 2008. Potassium silicate as foliar spray and rice blast control. $J$. Plant Nutr., 31: 231-237

Castilla, N., Savary, S., Veracruz, C.M. and Leung, H. 2009. Rice Blast: Rice Fact Sheets. International Rice Research Institute. pp. 1-3.

Chandrasekhara, M.V., Gururaj, S., Naik, M.K and Nagaraju, P. 2008. Screening of rice genotypes against rice blast cased by Pyriclaria oryzae Cavara. Karnataka Journal of Agricultural Sciences. 21(2): 305.

Chiba K, Tominaga T. and Urakawa F. 1996. Occurrence and control of rice blast disease in northern region of Iwate Prefecture in 1995. Annual Report of the Society of Plant Protection of North Japan. 47: pp. 8-10

Fernandez J and Orth K. 2018. Rise of a Cereal Killer: The Biology of Magnaporthe oryzae Biotrophic Growth. Trends in Microbiology, 26(7): 582-97, doihttps://doi.org/10.1016/j.tim.2017.12.0 07

Galbieri R and Urashima A. S. 2008. Sexual characterization, compatibility and occurrence of sexual reproduction among isolates of Pyricularia grisea from different hosts. Summa Phytopathologica 34: 22-28.

Groth, D. 2011. Rice blast management methods. $14^{\text {th }}$ Annual National Conservation Systems on Cotton and Rice Conference. pp. 12-14.

Hajano J.U., Lodhi A. M., Pathan M. A., Khanzada M. A. and Shah G. S. 2012. In vitroevaluation of fungicides, plant extracts and bio control agents against rice blast pathogen Magnaporthe oryzaeCouch. Pak. J. Bot.44: 177578.

Hajimo, K. 2001. Rice Blast Disease. Pesticide Outlook. pp. 23-25.

Hori S. 1898. Blast disease of rice plants. Special report, Imperial Agricultural Experimental Station, Tokyo 1:1-36.

Hossain M.D. 2000. Studies on Blast disease of rice caused by Pyricularia grisea (cooke) Sacc. in upland areas. M.Sc. Thesis, University of Agricultural Sciences, Dharwad. pp. 52-53.

Huang, S., Lu, J., Zhang, X and Qian, Q. 2005. Physiological macro lesions enhanced resistance to blast (Magnaporthe grisea) in rice near isogenic lines. Rice Science. 12(2): 148-150.

IRRI. 2009. Rice Policy-World Rice Statistics (WRS). Retrieved May 28, 2010. Linkhttp://www.irri.org/science/ricestat.

Kamel, S. M., \& El-Sharkawy, T. A. 1989. Management of rice blast disease in Egypt. In International Symposium on Rice Farming Systems, Sakha (Egypt), 31 Jan-3 Feb 1987. IRRI. pp.185-202

Khan, R.P and Libby, J.L. 1958. The effect of environmental factors and plant age on the infection of rice by the blast fungus, Pyricularia oryzae. Phytopathology, 48: 25-30.

Kumar A and Singh R A (1994) Host range of 
some isolates of Magnaporthe griseaand their grouping into forma specialis. Indian Phytopath210-12

Laane, H. M. 2018. The Effects of Foliar Sprays with Different Silicon Compounds. Plants, 7(45): 1-22. doi:10.3390/plants7020045

Leung $\mathrm{H}$, Borromeo E S, Bernaedo M A and Notteghem J L (1988) Genetic analysis of virulence in the rice blast fungus Magnaporthea grisea. Genetics Bethesda78: 1277- 333.

Liu YF, Chen ZY, Hu M, Li Lian and Liu YZ. 2004. Distribution of Magnaporthe grisea population and virulence of predominant race in Jiangsu Province, China. Rice Science. 11(3): 324-330.

Long D.H., Lee F.N. and Tebeest D.O. 2000. Effect of nitrogen fertilization on disease progress of rice blast on susceptible and resistant cultivars. Plant Disease 84: 403-9.

Mahesh, P, Shakywar, R.C, Dinesh, S and Shyam, S. 2012. Prevalence of insect pests, natural enemies and diseases in SRI (System of Rice Intensification) of rice cultivation in North Eastern Region. Annals of Plant Protection Sciences. 20 (2): 375-379.

Manandhar H. K. 1996. Rice blast disease: Seed transmission and induced resistance. Ph.D. thesis. The Royal Veterinary and Agricultural University.

Manibhushanrao K. and Day P.R. 1972. Low night temperature and blast disease development on rice. Phytopathology. 62: 1005-07.

Manibhushan Rao, K. 1994. Rice Blast Disease. 1stEd., Daya Publishing House, Delhi. 179.

Munoz, M.C. 2008. The effect of temperature and relative humidity on the airborne concentration of Pyricularia oryzae spores and the development of rice blast in Southern Spain. Spanish
Journal of Agricultural Research. 6(1): 61-69.

Nishikado, Y. 1917. Studies on the Rice Blast Fungus, (I). Berichte des Ohara Instituts für Landwirtschaftliche Forschungen, 1(2): 171-218.

Padmanabhan S.Y. 1965. Estimating losses from rice blast in India. In the rice blast disease, Johan Hopkins Press, Baltinoie, Maryland. pp. 203-21.

Padmanabhan S.Y. 1974. Fungal Diseases of Rice in India. 1st ed. Indian council of Agriculture Research, New Delhi. pp. 15 .

Ram, T., Majumder, T.N.D., Mishra, B., Ansari, M.M and Padmavathi, G. 2007. Introgression of broad spectrum blast resistance genes into cultivated rice (Oryza sativa sp. indica) from wild rice Oryza rufipogon. Current Science. 92 (2): 225-230.

Rossman, A.Y.R.J., Howard, B and Valent, B. 1990. Pyricularia grisea, the correct name for the rice blast fungus. Mycologia. 82: 509-512.

Saifulla Khan, A.M., Khan, N.A and Mohammad, Y. 2011. Effect of epidemiological factors on the incidence of paddy blast (Pyricularia oryzae) disease. Pakistan Journal of Phytopathology. 23 (2):108-111.

Seebold K.W., Datnoff L.E., Correa-Victoria F. 2000. Effect of silicon rate and host resistance on blast, scald, and yield of upland rice. Plant Disease 84: 871-6.

Sester M., Raveloson H., TharreauD. and Dusserre J. 2014. Conservation agriculture cropping system to limit blast disease in upland rainfed rice. Plant Pathology, 63(2): 373-381, doi: 10.1111/ppa.12099

Sharma, V. 2006. Integrated management of rice blast. Ph.D. thesis, Department of Plant Pathology, CSK Himachal Pradesh Krishi Vishvavidyalaya, Palampur (H.P.). pp. 1-117. 
Silue D. and Notteghem J. 1991. Resistance of 99 Oryza glaberrima varieties to blast. Int. Rice Res. News. 16, pp. 13-14.

Singh, S. R., Sunder, D.S., Dodan, D.S and Ram, L. 2011. Sources of resistance to blast and its management through chemicals. Journal of Mycology and Plant Pathoogy. 4(3): 422-425.

Subramanian S. 1967. Rice blast, nyctotemperature and metabolic changes. Phytopathology60: 41-50.

Sy A. A, Albertini L. and Hamant C. 1977. Effect of the $\mathrm{pH}$ on mycelial growth conidia formation and conidial germination of Pyriculariaoryzae. Bulletin de Toulouse Histoire naturella de Toulouse, 113: 200-11.

Tebeest D.O., Guerber C. and Ditmore M. 2007. Rice blast. The Plant Health Instructor. doi: 10.1094/PHI-I-20070313-07.

Urashima A.S., Leite S. and Galbieri R. 2007. Efficiency of aerial dissemination of Pyricularia grisea. Summa Phytopathologica 33: 275-79.

USDA. 2018. United States Department of
Agriculture Circular Series. WAP 12-18 december 2018.

https://apps.fas.usda.gov/psdonline/circulars/p roduction

Valent B. and Chumley F.G. 1991. Genes for cultivar specificity in the rice blast fungus, Magnaporthe grisea. In 'Signal molecules in plants interactions'. Berlin, Germany. pp. 415-22.

Varaprasada Rao, Ch. and Anil Kumar, P. 2018. Integrated Disease Management of Rice Blast Caused by Pyricularia grisea (Sacc.). Int. J. Curr. Microbiol. App. Sci. 7(03): 2952-2958. doi: https://doi.org/10.20546/ijcmas.2018.7 03.341

Veeraraghavan, $\mathbf{J}$ and Padmanabhan, S.Y. 1965. Studies on host range of Pyricularia oryzae Cav. Proceedings of Indian Academy of Sciences. 61: 109-120.

Zeigler RS, Leong SA and Teng P. 1994. Rice blast disease: International Rice Research Institute, Manila, Philippines.

\section{How to cite this article:}

Jiwan Paudel, Saroj Belbase, Shrvan Kumar, Rivesh Bhushal, Ramu Yadav and Dipak Yadav 2019. Eco-friendly Management of Blast (Magnaporthe oryzae) of Rice. Int.J.Curr.Microbiol.App.Sci. 8(09): 2610- 2619.doi: https://doi.org/10.20546/ijcmas.2019.809.302 